\title{
Effects of emitter discharge rates on soil salinity distribution and cotton (Gossypium hirsutum L.) yield under drip irrigation with plastic mulch in an arid region of Northwest China
}

\author{
Sulitan DANIERHAN ${ }^{1}$, Abudu SHALAMU $^{2 *}$, Hudan TUMAERBAI ${ }^{3}$, DongHai GUAN ${ }^{2}$ \\ ${ }^{1}$ State Key Laboratory of Desert and Oasis Ecology, Xinjiang Institute of Ecology and Geography, Chinese Academy of Sciences, \\ Urumqi 830011, China; \\ ${ }^{2}$ Xinjiang Institute of Water Resources and Hydroelectric Sciences, Urumqi 830049, China; \\ ${ }^{3}$ College of Water Conservancy and Civil Engineering, Xinjiang Agricultural University, Urumqi 830052, China
}

\begin{abstract}
A field experiment was carried out to investigate the effects of different emitter discharge rates under drip irrigation on soil salinity distribution and cotton yield in an extreme arid region of Tarim River catchment in Northwest China. Four treatments of emitter discharge rates, i.e. 1.8, 2.2, 2.6 and 3.2 L/h, were designed under drip irrigation with plastic mulch in this paper. The salt distribution in the range of $70-\mathrm{cm}$ horizontal distance and $100-\mathrm{cm}$ vertical distance from the emitter was measured and analyzed during the cotton growing season. The soil salinity is expressed in terms of electrical conductivity $(\mathrm{dS} / \mathrm{m})$ of the saturated soil extract $\left(\mathrm{EC}_{\mathrm{e}}\right)$, which was measured using Time Domain Reflector (TDR) 20 times a year, including 5 irrigation events and 4 measured times before/after an irrigation event. All the treatments were repeated 3 times. The groundwater depth was observed by SEBA MDS Dipper 3 automatically at three experimental sites. The results showed that the order of reduction in averaged soil salinity was $2.6 \mathrm{~L} / \mathrm{h}>2.2 \mathrm{~L} / \mathrm{h}>1.8 \mathrm{~L} / \mathrm{h}>3.2 \mathrm{~L} / \mathrm{h}$ after the completion of irrigation for the 3-year cotton growing season. Therefore, the choice of emitter discharge rate is considerably important in arid silt loam. Usually, the ideal emitter discharge rate is $2.4-3.0 \mathrm{~L} / \mathrm{h}$ for soil desalinization with plastic mulch, which is advisable mainly because of the favorable salt leaching of silt loam and the climatic conditions in the studied arid area. Maximum cotton yield was achieved at the emitter discharge rate of $2.6 \mathrm{~L} / \mathrm{h}$ under drip irrigation with plastic mulch in silty soil at the study site. Hence, the emitter discharge rate of $2.6 \mathrm{~L} / \mathrm{h}$ is recommended for drip irrigation with plastic mulch applied in silty soil in arid regions.
\end{abstract}

Keywords: drip irrigation; soil salinity; salt balance; cotton yield; emitter discharge rate

Citation: Sulitan DANIERHAN, Abudu SHALAMU, Hudan TUMAERBAI, DongHai GUAN. 2013. Effects of emitter discharge rates on soil salinity distribution and cotton (Gossypium hirsutum L.) yield under drip irrigation with plastic mulch in an arid region of Northwest China. Journal of Arid Land, 5(1): 51-59.

Water shortage and soil salinization are two key problems that limit the development of agriculture in arid regions (Douaoui et al., 2006; Chen et al., 2010; Karuppan and Minh-Long, 2010). At present, soil salinization has already become a global environmental hazard and ecological concern (Jin et al., 2007; Owojori et al., 2009; Zhang et al., 2009; Yuan et al., 2010). The soil salinization area reached as high as 9.5 mil- lion $\mathrm{km}^{2}$ globally and 1.0 million $\mathrm{km}^{2}$ in China which makes China one of the biggest soil salinization countries in the world. Xinjiang Uygur autonomous region, a typical arid region located in the northwestern part of China, has a soil salinization area of 0.2 million $\mathrm{km}^{2}$, accounting for $22 \%$ of the total salinized area in China (Wang and Jiang, 1991; Tashpolat et al., 2007; Wang et al., 2009). The most of the salinized area is

*Corresponding author: Abudu SHALAMU (E-mail: shalamu@yahoo.cn) Received 2012-04-13; revised 2012-06-10; accepted 2012-07-11

(C) Xinjiang Institute of Ecology and Geography, Chinese Academy of Sciences, Science Press and Springer-Verlag Berlin Heidelberg 2013 
located in the Tarim River catchment in South Xinjiang. The dry climate in the Tarim River catchment creates favorable conditions for the vertical movement of water and salt in soil (Yin et al., 2010). The main driving force for the upward movement of soil water is the intensive and extensive evapotranspiration in the basin. The existence of relatively high water tables provides a basic condition for groundwater evaporation. The dissolved salt in the groundwater moves upward continuously with the evaporation of soil water, and finally congregates in the surface of soil to cause severe soil salinization in the Tarim River catchment.

Under-film drip irrigation technique has been introduced into Xinjiang and is beneficial to enhance crop yield and utilization of water (Tiwari et al., 2003; Amayreh and Al-Abed, 2005; Xie et al., 2006; Ngouajio et al., 2007; Hou et al., 2010). It can also create a desalinized zone within the main root system of crops (Hanson et al., 2006) and facilitate the favorable development of ecological environment. The under-film drip irrigation technique was extended rapidly in Xinjiang due to the unique soil water and salt movement features in this region (Hu et al., 2009). The total area of under-film irrigation increased from $1000 \mathrm{hm}^{2}$ in 1999 to $0.6 \times 10^{6} \mathrm{hm}^{2}$ in $2009(\mathrm{Gu}, 2003$; Zhang et al., 2004; Li et al., 2009; Yin and Liu, 2009). When drip irrigation is applied in saline soils, it is crucial to develop a proper irrigation schedule that meets both crop water requirement and leaching requirement for salts added in irrigation water within the root zone. Several studies indicated that the salt contents in the inner part of the wetted zone were low and those in the outer area were high under properly maintained drip irrigation. In contrast, the distribution of water was quite different from salt distribution in the root zone, i.e. the water contents in the inner part of the wetted zone were higher than those in the outer part (Hanson and May, 2004; Palacios-Díaz et al., 2009). This unique distribution of soil water and salt under drip irrigation provides a better growing environment for crops in salt-affected soils.

In this study, a field experiment was conducted to test the effects of different drip irrigation regimes on soil salinity distribution and cotton yield in an arid region of Tarim River catchment in Northwest China.
The specific objectives were: (1) to test the effects of irrigation regimes (different drip irrigation water amount and drip discharge rates) on soil salinity and cotton yield in a silty loam field; and (2) to describe a management strategy by establishing safe irrigation regimes to maintain cotton productivity under drip irrigation with plastic mulch.

\section{Materials and methods}

\subsection{Study area}

The experiment was conducted in Aksu Agricultural Ecosystem National Scientific Research Station, Chinese Academy of Sciences, in Aksu, Xinjiang, China $\left(80^{\circ} 51^{\prime} \mathrm{E}, 40^{\circ} 37^{\prime} \mathrm{N}\right)$. The site is located near the intersection of three Tarim River branches (Aksu River, Yarkant River and Hotan River) and is 1,028 m high above the sea level. Compared to regions at the same latitude, the study area has extremely high summer temperatures, low winter temperatures, high evaporation (mean annual evaporation is $2,500 \mathrm{~mm}$ ), and scarce precipitation (mean annual precipitation is 45.7 $\mathrm{mm}$ ). Annual mean temperature is $11.2^{\circ} \mathrm{C}$, non-frost duration is $207 \mathrm{~d}$, annual sunlight hours are 2,940 h, annual mean wind speed is $2.4 \mathrm{~m} / \mathrm{s}$, and annual mean solar radiation is $6,000 \mathrm{MJ} / \mathrm{m}^{2}$. Main water source is snowmelt runoff from high mountains. The main growing crops in the area are cotton, rice and orchards.

\subsection{Design of drip irrigation systems}

The cotton field was irrigated every 8 days by drip irrigation during the growing season. The $1^{\text {st }}$ irrigation started on 29 May and the last irrigation was applied on 25 August, the total irrigation times being up to 12 times. The quality of irrigation water used for different treatments was quite good (Table 1).

Table 1 Chemical characteristics of the irrigation water

\begin{tabular}{ccccccccc}
\hline \multirow{2}{*}{$\mathrm{pH}$} & \multirow{2}{*}{$\begin{array}{c}\text { Salinity } \\
(\mathrm{g} / \mathrm{kg})\end{array}$} & \multicolumn{6}{c}{ Concentration $(\mathrm{g} / \mathrm{kg})$} \\
\cline { 3 - 9 } & $\mathrm{CO}_{3}{ }^{2-}$ & $\mathrm{HCO}_{3}{ }^{-}$ & $\mathrm{Cl}^{-}$ & $\mathrm{SO}_{4}{ }^{2-}$ & $\mathrm{Ca}^{2+}$ & $\mathrm{Mg}^{2+}$ & $\mathrm{K}^{+}+\mathrm{Na}^{+}$ \\
\hline 8.39 & 0.310 & 0.004 & 0.068 & 0.013 & 0.130 & 0.026 & 0.008 & 0.054 \\
\hline
\end{tabular}

The cotton cultivation patterns with plastic mulch are: four rows in one plastic mulch, the interspace between plastic mulches was $45 \mathrm{~cm}$; drip line space was $145 \mathrm{~cm}$; space between the emitters was $40 \mathrm{~cm}$; 
and plant space was $10 \mathrm{~cm}$ (Fig. 1). A drip tape was placed to irrigate four rows of cotton. Cotton (Gossypium hirsutum L.) seeds (cotton density: 27,000 plants $/ \mathrm{hm}^{2}$ ) were planted on 28 April, 2 May and 31 April of 2009, 2010 and 2011, respectively. The plastic mulches were applied over the cotton seed bed.

Each experimental plot had 60 measuring points: six points in horizontal direction from the emitter $(0$, $15,30,45,60$ and $72.5 \mathrm{~cm}$ ) and ten points in vertical direction from the surface to $100-\mathrm{cm}$ soil depth for each horizontal point at an even interval of $10 \mathrm{~cm}$ (Fig. 1).

\subsection{Fertilizer}

The cotton was planted on 28 April and $450 \mathrm{~kg} / \mathrm{hm}^{2}$ of ammonium phosphate was applied before planting. Urea and dihydropotassium were applied at 450 $\mathrm{kg} / \mathrm{hm}^{2}$ and $150 \mathrm{~kg} / \mathrm{hm}^{2}$, respectively with the $3^{\text {rd }}, 4^{\text {th }}$, $5^{\text {th }}$ and $6^{\text {th }}$ irrigations.

\subsection{Treatments}

To evaluate the effects of emitter discharge rates on soil salt distribution, four treatments with different emitter discharge rates were designed: 1.8, 2.2, 2.6 and $3.2 \mathrm{~L} / \mathrm{h}$. All the treatments were repeated three times, and for each repetition the location of the treatment in the field was randomly independent. The cultivation pattern and irrigation mode around the field were kept the same as the treatment located along borders to avoid the boundary effects. The size of each treatment plot was $4.35 \mathrm{~m} \times 1.6 \mathrm{~m}$, and the distance between the plots was $4.35 \mathrm{~m}$.

\subsection{Equipments and measurements}

In this study, the soil salinity is expressed in terms of electrical conductivity $(\mathrm{dS} / \mathrm{m})$ of the saturated soil extract $\left(\mathrm{EC}_{\mathrm{e}}\right)$, which was measured using Time Domain Reflector (TDR). Soil samples were obtained from soil cores extracted in the plot area with an auger on 2 June (the $4^{\text {th }}$ day after the $1^{\text {st }}$ irrigation), 21 July (the $5^{\text {th }}$ day after the $1^{\text {st }}$ irrigation) and on 31 August (the $6^{\text {th }}$ day after the last irrigation) in 2009, 2010 and 2011, respectively. All soil samples were air-dried and sieved through a 2-mm mesh. $\mathrm{EC}_{1: 5}$ was based on 1:5 soil/water extracts, and was determined using a conductivity meter. The relationships between $\mathrm{EC}_{\mathrm{e}}$ and $\mathrm{EC}_{1: 5}$ were determined after experiments and were used to convert $\mathrm{EC}_{1: 5}$ to $\mathrm{EC}_{\mathrm{e}}$ for all samples. For different soil textures, the relationships were different with different depths:

At $0-40 \mathrm{~cm}$ depth: $\mathrm{EC}_{\mathrm{e}}=8.55 \mathrm{EC}_{1: 5}\left(\mathrm{R}^{2}=0.76\right)$.

At $40-60 \mathrm{~cm}$ depth: $\mathrm{EC}_{\mathrm{e}}=6.91 \mathrm{EC}_{1: 5}\left(\mathrm{R}^{2}=0.89\right)$. (2)

There were 60 observation points in each experimental plot, i.e. 720 observation points in 12 experimental plots. The observation data were recorded at 18:00 $\mathrm{pm}$ on the $1^{\text {st }}, 3^{\text {rd }}$ and $7^{\text {th }}$ days after each irriga-

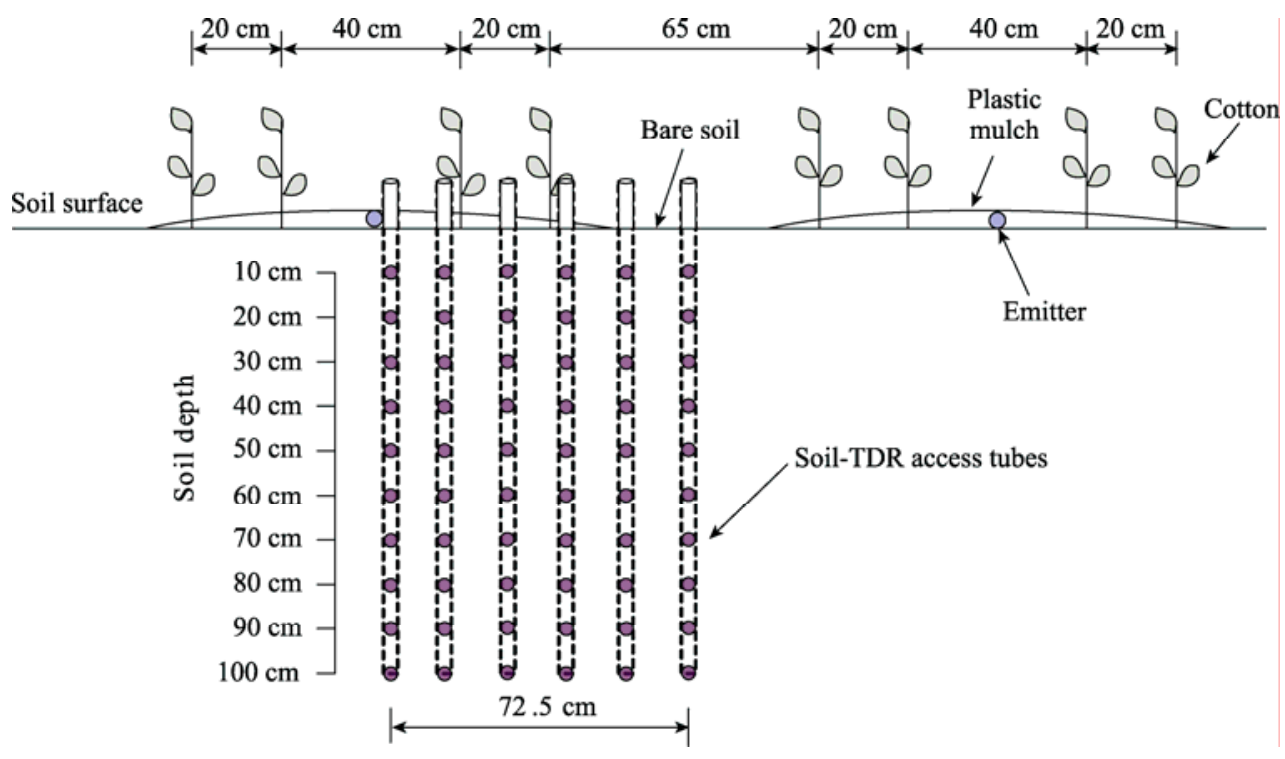

Fig. 1 The cultivation pattern of cotton and the position of Time Domain Reflection (TDR) access tubes 
tion. The electrical conductivities of the saturated soil extract $\left(E_{\mathrm{e}}\right)$ were measured with TDR 20 times a year, including 5 irrigation events and 4 measured times before/after an irrigation event. All the treatments were repeated 3 times.

The soil texture in the experimental site was silty loam. The main soil parameters are described in Table 2.

\subsection{Data Analysis}

The data process system (DPS) software was used to analyze the experimental data. The Surfer ver. 8.0 was used to describe and plot the spatial distribution features of soil salinity.

In this paper, we proposed a method of calculating average root zone soil salinity (Fig. 3). The denser the contour lines are, the higher the accuracy will be, and the more scattered they are, the more the possible error will be, namely:

$$
\bar{S}=\sum_{i=1}^{n}\left(A_{i}-A_{i-1}\right) \times\left(S_{i+1}+S_{i}\right) / 2 A .
$$

Where $\bar{S}$ is the average root zone soil salinity, $S_{i}$ the salinity of contour line $i$ at particular moment, $A_{i}$ the area between contour line $i$ and the contour line $i-1, A$ the total area, and $n$ the total number of contour lines.

\section{Results and discussion}

\subsection{Variation of climate factors and soil water content during the cotton growing season}

The cotton growing period started from 28 April and ended in 31 August, that is between the $18^{\text {th }}$ week and the $36^{\text {th }}$ week in 2009, 2010 and 2011, respectively. The temperature and solar radiation had similar variation pattern during the cotton growing period, i.e. in- creased from May to June and decreased from June onward. As indicated in Table 3, relative humidity had the opposite variation compared to temperature. The maximum weekly cumulative precipitation was 13.3 , 11.5 and $20.5 \mathrm{~mm}$ in 2009, 2010 and 2011, respectively; the cumulative precipitation for all growing seasons was 51.9, 42.0 and $61.5 \mathrm{~mm}$ in 2009, 2010 and 2011, respectively. Hence, the effects of precipitation on soil salinity can be neglected in this arid region. The main driving forces for the soil salinity variations were temperature, relative humidity and evapotranspiration; infiltration was very low under drip irrigation in this arid region. The amount of irrigation water and the rates of emitter discharge were changeless. The variation of soil water contents during the growing season was not obvious. The soil water contents decreased as the temperature increased (Table 3).

The groundwater depth was observed by SEBA MDS Dipper 3 automatically at three experimental sites. The groundwater table declined gradually throughout the cotton growing season due to high evapotranspiration in the arid region (Fig. 2). The soil water contents fluctuated repeatedly throughout the growing season; with each irrigation event the soil water content declined gradually over time. The relationship between groundwater table and soil water content was not significant as soil water could not recharge to groundwater under drip irrigation with plastic mulch, thus using more of the stored soil water between irrigations resulted in more soil water storage and less water reaching the groundwater table. There was minimal precipitation over the irrigation season and all stored soil water was from irrigation events.

Table 2 Soil physical properties measured at the experimental field

\begin{tabular}{|c|c|c|c|c|c|c|c|}
\hline \multirow{2}{*}{ Depth (cm) } & \multicolumn{3}{|c|}{ Textural fraction (\%) } & \multirow{2}{*}{ Texture class } & \multirow{2}{*}{$\begin{array}{l}\text { Soil bulk density } \\
\qquad\left(\mathrm{g} / \mathrm{cm}^{3}\right)\end{array}$} & \multirow{2}{*}{$\begin{array}{l}\text { Saturation water content } \\
(\%)\end{array}$} & \multirow{2}{*}{$\begin{array}{l}\text { Saturated hydraulic conductivity } \\
\qquad(\mathrm{cm} / \mathrm{d})\end{array}$} \\
\hline & Sand & Silt & Clay & & & & \\
\hline $0-10$ & 62.3 & 37.4 & 0.3 & Silt sand & 1.37 & 45.3 & 27.3 \\
\hline $10-20$ & 51.9 & 46.2 & 1.9 & Silt sand & 1.45 & 48.3 & 12.5 \\
\hline $20-30$ & 38.4 & 59.1 & 2.5 & Silty loam & 1.54 & 48.2 & 8.9 \\
\hline $30-40$ & 51.3 & 47.3 & 1.4 & Silt sand & 1.44 & 42.3 & 11.4 \\
\hline $40-60$ & 40.6 & 57.2 & 2.2 & Silty loam & 1.47 & 48.2 & 9.3 \\
\hline $60-80$ & 33.2 & 63.9 & 2.9 & Silty loam & 1.48 & 47.4 & 4.7 \\
\hline $80-100$ & 32.7 & 64.0 & 3.3 & Silty loam & 1.52 & 48.6 & 4.5 \\
\hline
\end{tabular}


Table 3 Weather and soil data during the whole cotton growing period in 2009, 2010 and 2011

\begin{tabular}{|c|c|c|c|c|c|c|c|c|c|c|c|c|c|c|c|}
\hline \multirow{2}{*}{ Week } & \multicolumn{3}{|c|}{$\begin{array}{c}\text { Temperature } \\
\left({ }^{\circ} \mathrm{C}\right)\end{array}$} & \multicolumn{3}{|c|}{ Relative humidity (\%) } & \multicolumn{3}{|c|}{$\begin{array}{c}\text { Volumetric soil water } \\
\text { content }(\%)\end{array}$} & \multicolumn{3}{|c|}{$\begin{array}{l}\text { Pan evaporation } \\
\text { (mm/day) }\end{array}$} & \multicolumn{3}{|c|}{$\begin{array}{c}\text { Cumulative precipitation } \\
\text { (mm/week) }\end{array}$} \\
\hline & 2009 & 2010 & 2011 & 2009 & 2010 & 2011 & 2009 & 2010 & 2011 & 2009 & 2010 & 2011 & 2009 & 2010 & 2011 \\
\hline $18^{\text {th }}$ & 23.0 & 21.4 & 19.7 & 26.0 & 33.5 & 37.9 & 22.6 & 23.0 & 24.2 & 11.8 & 10.2 & 7.6 & 0.0 & 2.1 & 8.5 \\
\hline $19^{\text {th }}$ & 18.0 & 19.5 & 17.5 & 27.3 & 29.4 & 26.0 & 20.8 & 21.5 & 22.1 & 11.6 & 12.8 & 9.6 & 0.0 & 0.2 & 0.0 \\
\hline $20^{\text {th }}$ & 23.2 & 24.1 & 23.0 & 35.6 & 29.0 & 31.0 & 21.3 & 18.0 & 20.3 & 14.6 & 13.1 & 10.8 & 8.1 & 0.0 & 0.0 \\
\hline $21^{\mathrm{st}}$ & 23.9 & 22.0 & 22.8 & 24.5 & 27.6 & 26.6 & 19.0 & 20.4 & 19.5 & 14.3 & 11.3 & 11.9 & 0.0 & 0.0 & 0.0 \\
\hline $22^{\text {nd }}$ & 24.3 & 25.3 & 24.7 & 25.0 & 23.7 & 27.4 & 20.3 & 19.3 & 20.1 & 13.3 & 15.6 & 12.2 & 0.0 & 0.0 & 0.0 \\
\hline $23^{\mathrm{rd}}$ & 24.7 & 21.0 & 25.2 & 24.6 & 31.0 & 23.1 & 18.0 & 19.8 & 17.8 & 14.8 & 13.0 & 15.6 & 0.0 & 0.5 & 0.0 \\
\hline $24^{\text {th }}$ & 24.8 & 24.1 & 23.3 & 39.4 & 32.4 & 38.0 & 15.8 & 16.1 & 17.0 & 15.7 & 14.4 & 10.8 & 3.7 & 0.3 & 2.3 \\
\hline $25^{\text {th }}$ & 23.0 & 21.6 & 23.9 & 43.6 & 37.9 & 35.2 & 23.5 & 20.2 & 18.3 & 12.3 & 9.5 & 13.3 & 13.3 & 7.0 & 0.7 \\
\hline $26^{\text {th }}$ & 26.0 & 27.5 & 26.2 & 43.5 & 38.6 & 40.4 & 22.0 & 17.6 & 21.3 & 10.0 & 12.2 & 10.0 & 9.5 & 0.0 & 2.4 \\
\hline $27^{\text {th }}$ & 25.2 & 23.8 & 24.0 & 53.2 & 56.4 & 55.0 & 21.2 & 22.9 & 22.7 & 15.1 & 9.4 & 12.0 & 0.0 & 8.5 & 6.2 \\
\hline $28^{\text {th }}$ & 23.7 & 23.2 & 22.9 & 52.9 & 47.7 & 49.0 & 19.3 & 18.7 & 19.0 & 12.7 & 9.8 & 9.8 & 2.6 & 0.0 & 1.2 \\
\hline $29^{\text {th }}$ & 27.7 & 25.0 & 26.2 & 39.0 & 43.2 & 37.7 & 21.2 & 23.0 & 21.5 & 12.2 & 7.9 & 11.0 & 3.9 & 8.1 & 1.6 \\
\hline $30^{\text {th }}$ & 29.4 & 27.3 & 29.0 & 35.7 & 51.0 & 47.3 & 20.3 & 23.8 & 23.0 & 8.7 & 8.9 & 10.3 & 0.0 & 11.5 & 5.0 \\
\hline $31^{\mathrm{st}}$ & 29.2 & 30.0 & 30.8 & 44.5 & 46.3 & 41.6 & 22.5 & 21.9 & 21.6 & 6.6 & 8.3 & 10.7 & 0.0 & 1.7 & 0.0 \\
\hline $32^{\text {nd }}$ & 25.8 & 26.1 & 22.7 & 51.2 & 48.1 & 53.4 & 22.7 & 22.1 & 24.1 & 9.1 & 9.3 & 5.7 & 4.5 & 2.1 & 12.9 \\
\hline $33^{\mathrm{rd}}$ & 24.8 & 26.0 & 25.1 & 50.0 & 45.9 & 46.9 & 21.8 & 19.7 & 20.0 & 8.8 & 11.6 & 9.3 & 0.0 & 0.0 & 0.0 \\
\hline $34^{\text {th }}$ & 24.3 & 24.9 & 24.0 & 52.8 & 47.3 & 51.2 & 22.3 & 21.8 & 22.0 & 8.5 & 11.1 & 9.4 & 0.0 & 0.0 & 0.2 \\
\hline $35^{\text {th }}$ & 22.6 & 23.0 & 19.5 & 51.2 & 42.0 & 57.3 & 23.6 & 20.9 & 24.8 & 7.6 & 9.1 & 6.2 & 6.3 & 0.0 & 20.5 \\
\hline
\end{tabular}

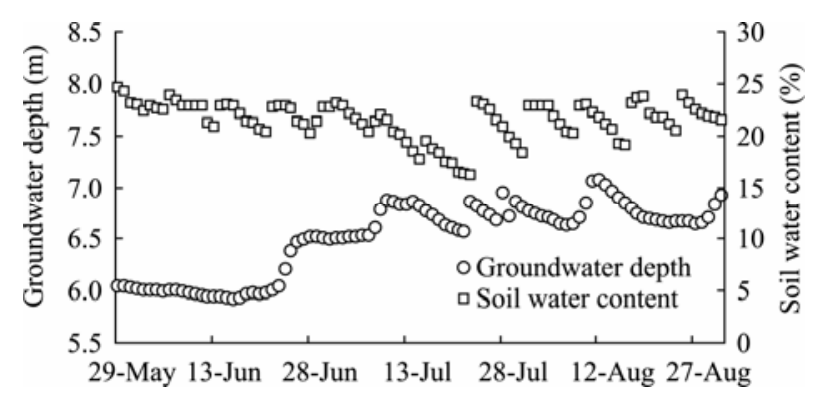

Fig. 2 The relationship between groundwater table fluctuation and soil water content at middle growing stages

\subsection{Variation of soil salinity with emitter dis- charge rates}

The soil salinity distribution under the plastic mulch and between the mulches remained different. After drip irrigation, soil salinity increased with the distance from the emitter (Fig. 3).

The possible reason is that, with the movement of soil wetting front, salt under the plastic mulch leached in an ellipse shape to the right and downward direction. Because the plastic mulch limited evaporation from soil, salt in the soil gradually moved to the bare soil surface between the zones of plastic mulches due to higher evaporation compared to that under the mulch. With the upward movement of salt, salt accumulation in the bare soil surface between the plastic mulches is a natural consequence (Zhao et al., 2009). The average salinity of the bare soil between mulches at $0-30 \mathrm{~cm}$ layer was significantly higher than that in soil under mulch, while it was reversed at $30-60 \mathrm{~cm}$ soil layer, but differences leveled off at $60-100 \mathrm{~cm}$ soil layer in each year.

As shown in Fig. 3, with the increment of emitter discharge rates, vertical and horizontal movement of soil salinity increased at early stages and decreased at later stages. At further increment, the infiltration capacity of soil pores became smaller than the emitter discharge. As a result, the downward movement of soil salinity was influenced by the movement of water in soil. When emitter discharge rate reached $3.2 \mathrm{~L} / \mathrm{h}$, the vertical distance between soil desalinization zones decreased significantly (Fig. 3). More specifically, in silty soil, when the emitter discharge reached a certain intensity (usually $>3.0 \mathrm{~L} / \mathrm{h}$ ), soil moisture broadened but to less depth with the increment of emitter discharge rates due to the constraint of infiltration capacity (the drip emitter intensity was higher than that of soil infiltration). Therefore high-intensity emitter discharge is favorable to the horizontal leaching of soil salinity rather than the transport of salt to deeper soil layers. 


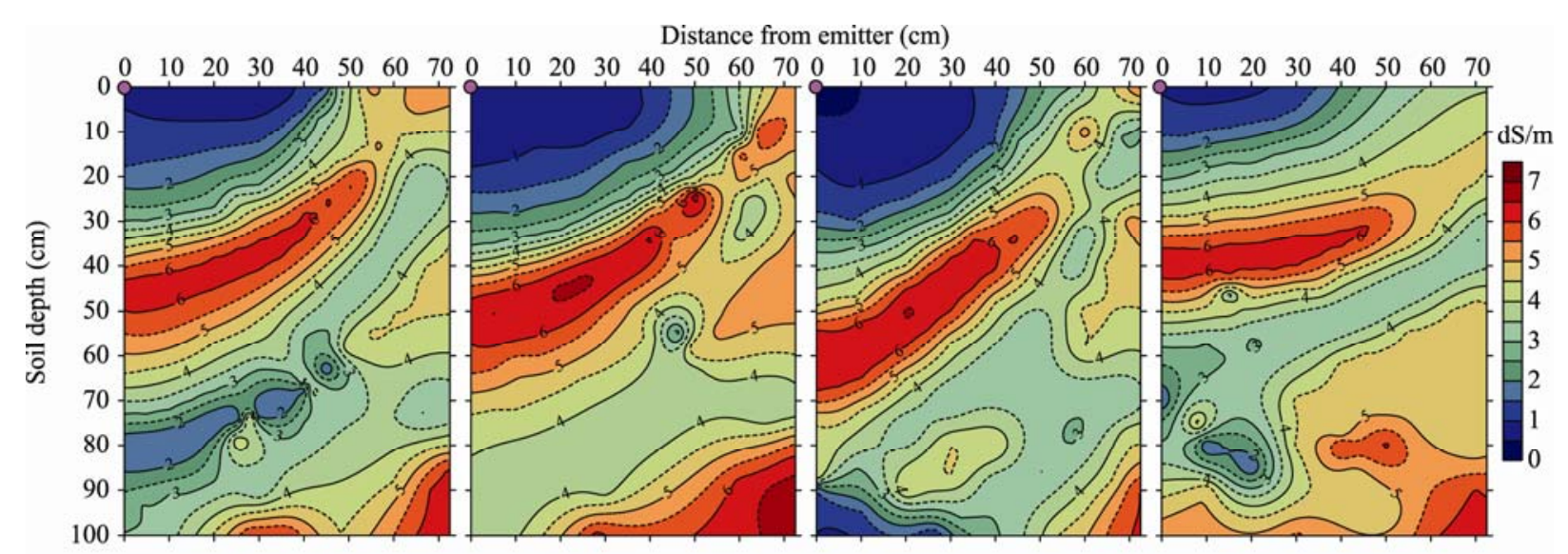

(a) 2009

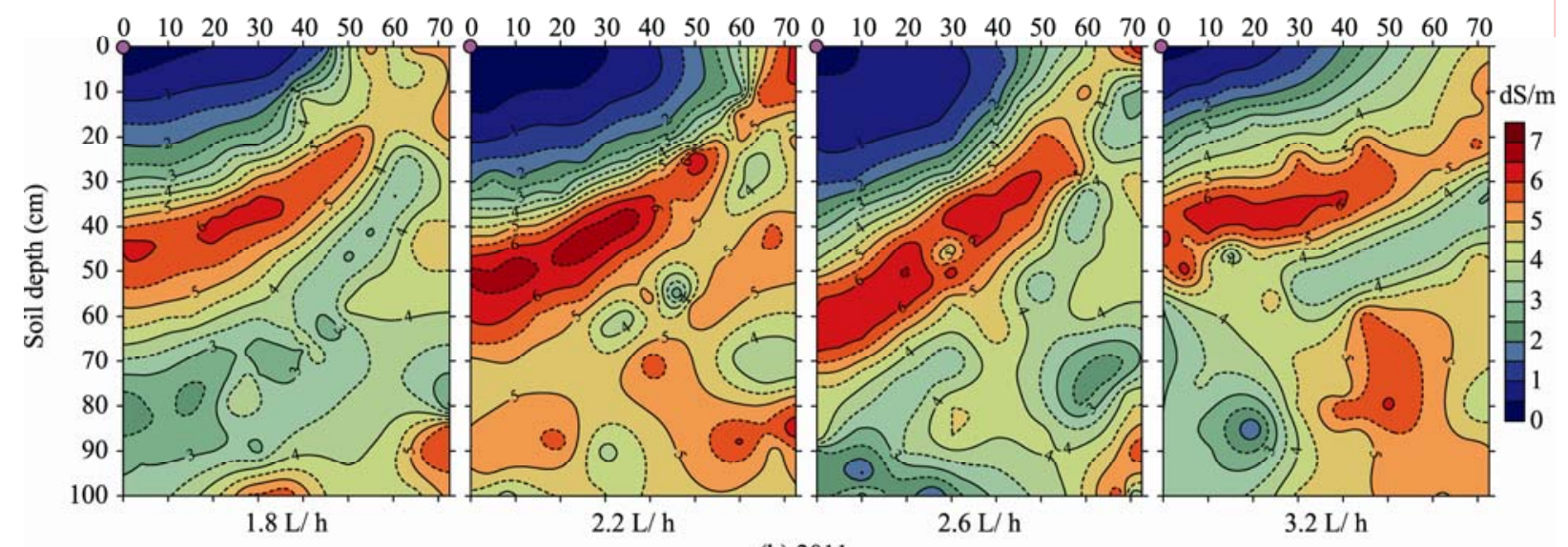

(b) 2011

Fig. 3 The spatial distribution of soil salinity $\left(E C_{e}\right.$, expressed in $\left.\mathrm{dS} / \mathrm{m}\right)$ in the vertical transect perpendicular to the drip tapes for different emitter discharge rates at middle growing stages in 2009 and 2011

The order of reduction in soil salinity was $2.6 \mathrm{~L} / \mathrm{h}>$ $2.2 \mathrm{~L} / \mathrm{h}>1.8 \mathrm{~L} / \mathrm{h}>3.2 \mathrm{~L} / \mathrm{h}$ after the completion of irrigation during the cotton growing season for the 3 -year period. Therefore, the choice of emitter discharge rate is considerably important in arid silt loam. Usually, the ideal emitter discharge rate is $2.4-3.0 \mathrm{~L} / \mathrm{h}$ for soil desalinization with plastic mulch, which is advisable mainly because of the structure of silt loam and the climatic conditions in this arid area.

\subsection{Change of soil salinity over time}

The soil salinity tended to move upward from deeper soil to soil surface and from under the mulch toward between the mulches as time passed after irrigation (Fig. 4). This is mainly because the plastic mulch limited the unproductive evaporation from soil. With the driving force of evaporation, both soil moisture and salinity move upward to the soil surface between the plastic mulches. Therefore, the order of soil desalini- zation ratio was 1 day after irrigation $>3$ days after irrigation $>7$ days after irrigation $>$ before irrigation in the whole experimental stage. This indicated that, under the driving force of evaporation process, the soil salinity moves upward gradually as the soil moisture moved to the soil surface, and finally causes the constant of shrink of soil desalinization zone under the plastic mulch.

In a desalinization zone surrounded by $\mathrm{EC}_{\mathrm{e}}=1.5$ $\mathrm{dS} / \mathrm{m}$ contour lines, the average areas of desalinization after 1,3 and 7 days of drip irrigation were 1,886, 1,078 and $856 \mathrm{~cm}^{2}$, respectively for the 3 -year period (Table 4). The results in Table 4 clearly show that the soil salinity declined more rapidly after 1 day of irrigation due to soil salinity leaching by soil water movement, and the soil salinity rose over time till the next irrigation event occurred, which may explain the importance of drip irrigation with plastic mulch to soil desalinization in arid regions. 


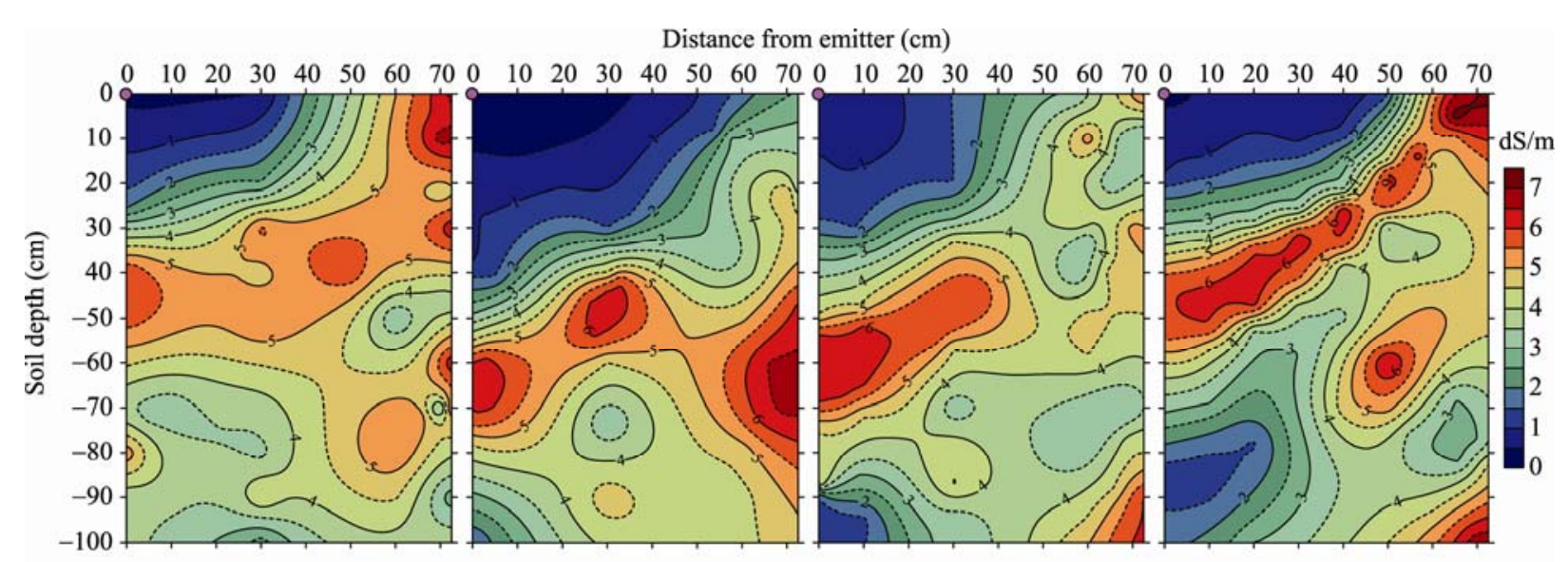

(a) 2009

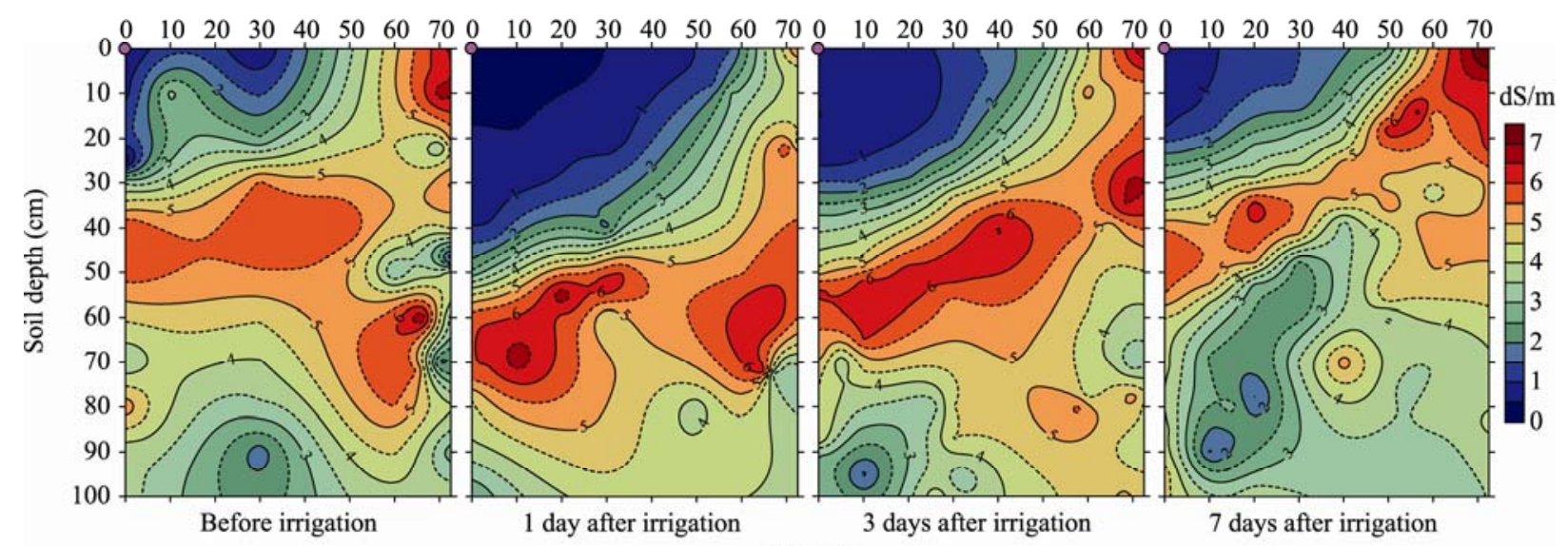

(b) 2011

Fig. 4 The spatial distribution of soil salinity $\left(\mathrm{EC}_{\mathrm{e}}\right.$, expressed in $\left.\mathrm{dS} / \mathrm{m}\right)$ before and after drip irrigation at middle growing stages in 2009 and 2011

Table 4 The area of desalinization before and after irrigation at middle growing stages in 2009, 2010 and 2011

\begin{tabular}{ccccc}
\hline Year & Before irrigation $\left(\mathrm{cm}^{2}\right)$ & 1 day after irrigation $\left(\mathrm{cm}^{2}\right)$ & 3 days after irrigation $\left(\mathrm{cm}^{2}\right)$ & 7 days after irrigation $\left(\mathrm{cm}^{2}\right)$ \\
\hline 2009 & 814 & 1,881 & 1,039 & 970 \\
2010 & 838 & 1,760 & 991 & 806 \\
2011 & 769 & 2,017 & 1,204 & 792 \\
Average & 807 & 1,886 & 1,078 & 856 \\
\hline
\end{tabular}

\subsection{Salt balance at root zone during the cotton growing season}

Balance of soil salinity is one of the main indicators that measure the salinity accumulation or desalinization in a certain irrigation zone (Zhao et al., 2009). Soil salinity balance at early and late stages of cotton growing season can be used as an indicator of secondary salinization. In the cotton growing season, soil salinity decreased generally at the end compared to at the beginning of the drip irrigation season at all emit- ter discharge rates with the exception of emitter discharge rates at $3.2 \mathrm{~L} / \mathrm{h}$ (Fig. 5).

The desalination area was characterized by $\mathrm{EC}_{\mathrm{e}}<1.5$ $\mathrm{dS} / \mathrm{m}$ and surrounded by $1.5 \mathrm{EC}_{\mathrm{e}}$ contour lines. The balance was made for root zone $0-40 \mathrm{~cm}$, but salt accumulation took place at the soil layer of $0-100 \mathrm{~cm}$ at the end of drip irrigation season. Root zone salt balance equation can be simplified as:

$$
\Delta S=S_{2}-S_{1} \text {. }
$$

Where $\Delta S$ is the variation of soil salinity, $S_{2}$ the soil 


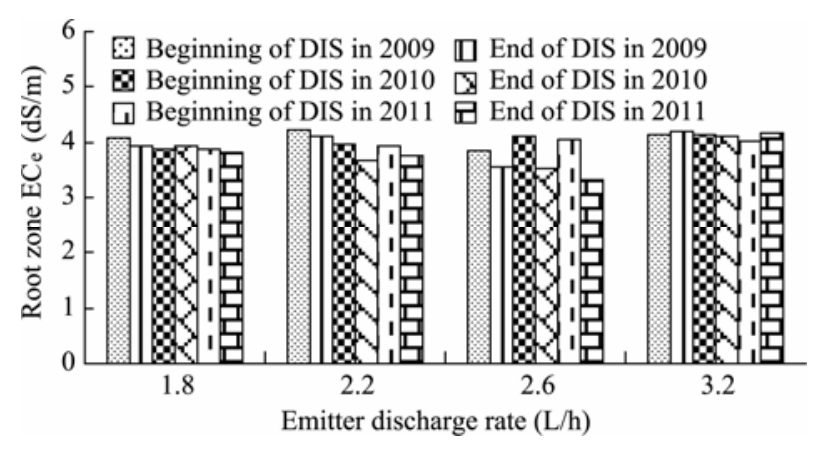

Fig. 5 The average cotton root zone soil salinity at the beginning and the end of the drip irrigation season (DIS) in 2009, 2010 and 2011

salinity after irrigation, and $S_{1}$ the soil salinity before irrigation. $\Delta S>0$ represents salt accumulation, $\Delta S<0$ desalinization, and $\Delta S=0$ no change in $\mathrm{EC}_{\mathrm{e}}$ (Zhao et al., 2009).

Compared to the beginning of the experiment, the average cotton root zone salinity at $0-40 \mathrm{~cm}$ soil layer decreased at the termination of the experiment with the exception of emitter discharge rate at $3.2 \mathrm{~L} / \mathrm{h}$ in 2009 and 2011, and $1.8 \mathrm{~L} / \mathrm{h}$ in 2010 (Fig. 5). Under the treatment at $1.8,2.2$ and $2.6 \mathrm{~L} / \mathrm{h}$, the average soil desalinization ratio was $1.4 \%, 5.1 \%$ and $15.7 \%$, respectively, but salt accumulation occurred at $3.2 \mathrm{~L} / \mathrm{h}$ treatment with the ratio of $1.3 \%$ for the 3 -year period. This indicated that throughout the cotton growing season, developing a reasonable under-film drip irrigation scheme is helpful for desalinization at the shallow soil layer. The possible reason is that the ground water table in the study area is relatively high (200-300 cm), and soil salt moves upward as the evaporation progresses (Zhao et al., 2009) as groundwater table has certain impacts on inter-annual variations of soil salinity. The experimental data presented above indicated that the emitter discharge rate $2.6 \mathrm{~L} / \mathrm{h}$ is advisable for the irrigation of silt loam soils in arid areas mainly because of their high internal drainage (Zhao et al., 2009). With further increment of the emitter discharge, vertical movement of soil salt will be restricted due to limited soil infiltration, and salt will not leach into deeper soil layers. Therefore, some relevant techniques such as combined directional leaching of water and salt under drip irrigation conditions could be utilized to improve the process of salt leaching.

\subsection{Impact of different emitter discharge rates on cotton yield}

Irrigation treatments have significant influences on cotton yield (Fig. 6) and cotton yield increased with the increment of the emitter discharge rates for silt loam soil. However, beyond $3.0 \mathrm{~L} / \mathrm{h}$, cotton yield began to decrease owing to the accumulation of salt as shown in Fig. 3. Cotton yield was lower at both high $(3.2 \mathrm{~L} / \mathrm{h})$ and low $(1.8 \mathrm{~L} / \mathrm{h})$ emitter discharge rates. In contrast, higher yield of cotton was obtained at moderate emitter discharge rates of 2.2 and $2.6 \mathrm{~L} / \mathrm{h}$. This indicated that either a small or a large emitter discharge rate is beneficial for cotton production. Therefore, the emitter discharge rate of $2.6 \mathrm{~L} / \mathrm{h}$ resulted in a maximum cotton yield of $6,873 \mathrm{~kg} / \mathrm{hm}^{2}$, and is highly recommended for silt loam soil under drip irrigation with plastic mulch in arid regions.

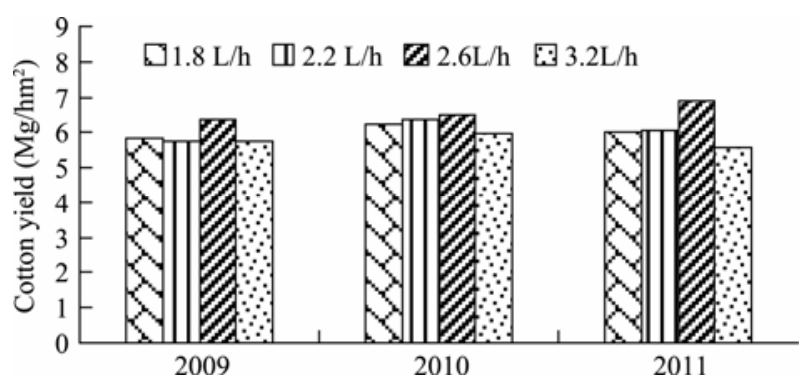

Fig. 6 Cotton yield under different emitter discharge rate treatments in 2009, 2010 and 2011

\section{Conclusions}

Due to the irrigation measures and natural factors, secondary salinization still exists in the cotton fields under drip irrigation with plastic mulch in the arid area where the re-distribution of soil moisture determines the distribution of soil salinity. According to the results of our research, it was concluded that irrigation emitter discharge rates had a significant effect on soil salinity distribution and cotton yield. With the increment of emitter discharge rates, both horizontal and vertical distances of the movement of soil salt showed a tendency of increase at early stages and a tendency of decrease at later stages for the 3-year period. The moderate emitter discharge rate of $2.2-2.6 \mathrm{~L} / \mathrm{h}$ seems to be an appropriate solution. From the experiment, it 
can be concluded that either a small or a large emitter discharge rate is beneficial for cotton yield, the emitter discharge rate $2.6 \mathrm{~L} / \mathrm{h}$ is most advisable for achieving the maximum cotton yield under drip irrigation with plastic mulch in silt loam at the study area.

\section{Acknowledgements}

This research was financially supported by the National Basic Research Program of China (2009CB421302) and the National Natural Science Foundation of China (41071026, 51069017).

\section{References}

Amayreh J, Al-Abed N. 2005. Developing crop coefficients for field-grown tomato (Lycopersicon esculentum Mill.) under drip irrigation with black plastic mulch. Agricultural Water Management, 73(3): 247-254.

Chen W P, Hou Z N, Wu L S, et al. 2010. Evaluating salinity distribution in soil irrigated with saline water in arid regions. Agricultural Water Management, 97(12): 2001-2008.

Douaoui A E K, Nicolas H, Walter C. 2006. Detecting salinity hazards within a semiarid context by means of combining soil and remote-sensing data. Geoderma, 134(1-2): 217-230.

Gu L F. 2003. Formation and development of cotton drip irrigation under mulch in the Xinjiang Production and Construction Corps. Water Saving Irrigation, 28(1): 27-29.

Hanson B, May D. 2004. Effect of subsurface drip irrigation on processing tomato yield, water table depth, soil salinity, and profitability. Agricultural Water Management, 68(1): 1-17.

Hanson B R, Šimůnek J, Hopmans J W. 2006. Evaluation of urea-ammonium- nitrate fertigation with drip irrigation using numerical modeling. Agricultural Water Management, 86(1-2): 102-113.

Hou X Y, Wang F X, Han J J, et al. 2010. Duration of plastic mulch for potato growth under drip irrigation in an arid region of Northwest China. Agricultural and Forest Meteorology, 150(1): 115-121.

Hu X T, Chen H, Wang J, et al. 2009. Effects of soil water content on cotton root growth and distribution under mulched drip irrigation. Agricultural Sciences in China. 8(6): 709-716.

Jin Z M, Wang C H, Liu Z P, et al. 2007. Physiological and ecological characters studies on Aloe vera under soil salinity and seawater irrigation. Process Biochemistry, 42(4): 710-714.

Karuppan S, Minh-Long N. 2010. Extent, impact, and response to soil and water salinity in arid and semiarid regions. Advances in Agronomy, 109(1): 55-74.

Li Y Y, Pang H C, Chen F, et al. 2009. Effect of drip irrigation under plastic mulch on aeolian sandy soil salt dynamic and cotton yield. Journal of Soil and Water Conservation, 23(4): 96-100.

Ngouajio M, Wang G Y, Goldy R. 2007. Withholding of drip irrigation between transplanting and flowering increases the yield of field-grown tomato under plastic mulch. Agricultural Water Management, 87(3): 285-291.

Owojori O J, Reinecke A J, Voua-Otomo P, et al. 2009. Comparative study of the effects of salinity on life-cycle parameters of four soil-dwelling species (Folsomia candida, Enchytraeus doerjesi, Eisenia fetida and Aporrectodea caliginosa). Pedobiologia. 52(6): 351-360.

Palacios-Díaz M P, Mendoza-Grimón V, Fernández-Vera $\mathrm{J}$ R, et al. 2009. Subsurface drip irrigation and reclaimed water quality effects on phosphorus and salinity distribution and forage production. Agricultural Water Management, 96(11): 1659-1666.

Tashpolat T, Zhang F, Zhao R, et al. 2007. Selected methods and empirical analysis of extracting salinization information in the arid area of Xinjiang. Chinese Journal of Soil Science, 38(4): 625-630.

Tiwari K N, Singh A, Mal P K. 2003. Effects of drip irrigation on yield of cabbage (Brassica oleracea L. var. capitata) under mulch and non-mulch conditions. Agricultural Water Management, 58(1): $19-28$.

Wang G Q, Jiang D H. 1991. Problem and game of salinization and desertification in land usage of oasis. China Land Science, 5(4): 24-28.

Wang Y G, Li Y, Xiao D N. 2009. Effects of land use type on soil salinization at northern slope of Tianshan Mountain. Journal of Soil and Water Conservation, 23(5): 179-183.

Xie Z K, Wang Y J, Wei X H, et al. 2006. Impacts of a gravel-sand mulch and supplemental drip irrigation on watermelon (Citrullus lanatus [Thunb.] Mats. \& Nakai) root distribution and yield. Soil and Tillage Research, 89(1): 35-44.

Yin B, Liu Y T. 2009. Spatial distribution and accumulation pattern of soil salinity with long term drip irrigation under plastic mulching. Agricultural Research in the Arid Areas, 27(6): 228-231.

Yin C H, Feng G, Zhang F S, et al. 2010. Enrichment of soil fertility and salinity by tamarisk in saline soils on the northern edge of the Taklamakan Desert. Agricultural Water Management, 97(12): 1978-1986.

Yuan J F, Feng G, Ma H Y, et al. 2010. Effect of nitrate on root development and nitrogen uptake of suaeda physophora under $\mathrm{NaCl}$ salinity. Pedosphere, 20(4): 536-544.

Zhang F, Tashpolat T, Ding J L, et al. 2009. The effects of the chemical components of soil salinity on electrical conductivity in the region of the delta oasis of Weigan and Kuqa Rivers, China. Agricultural Sciences in China, 8(8): 985-993.

Zhang Q, Li G Y, Cai F J. 2004. Effect of mulched drip irrigation frequency on soil salt regime and cotton growth. Journal of Hydraulic Engineering. 35(9): 123-126.

Zhao C Y, Yan Y Y, Li J Y, et al. 2009. Distributed characteristics of soil water-salt of cotton field under drip irrigation under mulching in Tarim Irrigated Area. Arid Land Geography, 32(6): 892-898. 